would be about $£ 30$ per month, including living expenses and tuition. The group has already in draft a memorandum and articles of association, and is prepared to incorporate the College and to form an initial court of governors.

\section{Eratosthenes and the Circumference of the Earth}

In Sky and Telescope of September, under the heading "Saluting an Astronomer", Joseph R. Habes has an article which describes the method adopted by Eratosthenes for measuring the circumference of the earth. He knew that the sun threw no shadow at the summer solstice at Syene (the modern Assuan) and at the same hour at Alexandria the pointers of the sundials threw shadows, because Alexandria is north of Syene. He found that the arc of the shadow in the hemispherical bowl of the sundial was 1/50 of its circle, and hence concluded that the arc of the earth between Syene and Alexandria, which was 5,000 stadia, was $1 / 50$ of the great circle of the earth. By this means he found that the circumference of the earth was 250,000 stadia, according to Cleomedes, but Strabo says that it was 252,000 stadia. A discrepancy arises when we come to consider the length of the stadium. The Greek stadium was $606 \cdot 75 \mathrm{ft}$., and if Eratosthenes used this he was obviously very much in error in his computation. On the other hand, Pliny in his "Naturalis Historia" claims that Eratosthenes made 40 stadia equal to the Egyptian schoinus, and if this be so, taking the schoinus as 12,000 royal cubits of 0.525 metres each, the length of the stadium was $516 \cdot 73 \mathrm{ft}$. If we accept the account of Strabo that Eratosthenes measured the circumference of the earth as 252,000 stadia, the circumference would be 24,662 miles, and the polar diameter 7,850 miles-only 50 miles short of the true polar diameter. This is considered to be one of the first great triumphs of scientific calculation.

\section{Association of Scientific Workers : Scientific Film Group}

$I_{N}$ view of the rapid increase in the applications of photography in science and industry, the West Midland Area of the Association of Scientific Workers has formed a Scientific Film Group. By means of lectures, exhibitions and news letters containing abstracts of recent publications, the Group will provide information for scientific workers using photographic techniques in industrial processes and research laboratories. The Group will also foster interest in the manifold applications of photography. It has already set up an information service able to provide expert advice on all aspects of photographic technique. The Group will endeavour to meet the demand of the general public for good-quality scientific films covering the whole field of science and technology. Monthly film shows will be held in Birmingham throughout this winter. The first show will take place in the middle of November. In the future the Group intends to produce original films and photographs. Applications for membership and inquiries should be addressed to Mr. H. Zerkowsky, Rowney Green, Nr. Alvechurch, Wores.

\section{Early Scientific Works}

Catalogue 8, recently published by Davis and Orioli of 1 St. Martin's Street, Wallingford, Berks, contains a collection of 143 items printed before 1500 . In addition to works on theology, philosophy and literature, heraldry and cookery, science and medieine are presented by the following works, among others : Albertus Magnus, "De secretis mulierum" (c. 1500); Aristotle, "De numero Partium" (c. 1490); Bartholomoeus Anglicus, "El libro de proprietatibus" (1494) ; Capillutus, "De curatione pestiferorum" (c. 1487) ; Celsus, "De medicina" (1497); Decembrius, "De Genitura Hominis" (c. 1495); Mesue's "Opera Omnia" (1497) ; Savonarola, "Practic in Medicina" (1498) and Silvaticus, "Opus Panectarum Medicinæ" (1498).

\section{Announcements}

DR. B. A. KeEN, assistant director at Rothamsted Experimental Station, will ke absent from Rothamsted for approximately twelve months, acting as a scientific adviser to the Middle East Supply Centre, Cairo. He will report on the scientific and technical problems and resources (including personnel) in the area, and make recommendations on the establishment of a suitable organization, in the Middle East and elsewhere, to ensure the fullest practicable service of information and advice, with special reference to the post-war period. Dr. Keen will deal with agricultural resources and development and related problems, including education. He will be accompanied by Dr. E. B. Worthington, who will examine various non-agricultural matters. An American representative is expected to join the mission at a later date. The countries to be visited extend from Persia to Libya and from Turkey to the Sudan. It is hoped that the mission will be able to report by November 1944.

THe following appointments and promotions in the Colonial Service have recently been made: P. S. Hammond, agrieuitural superintendent, Gold Coast; D. K. MeEwan Kevan, agricultural officer, Kenya; W. V. Rose, agricultural officer, Nyasaland; R. O. Williams, agricultural officer, Kenya ; H. B. Atkinson, inspector of plants and produce, Gold Coast; G. G. Robinson, entomologist, Medical Department, Northern Rhodesia; N. S. Stevenson (conservator of forests, British Honduras), conservator of forests, Nigeria.

THE following appointments in the University of Sheffield have recently been made: Dr. A. I. G. McLaughlin (H.M. medical inspector of factories), honorary lecturer in industrial medicine in the De. partment of Public Health; Mr. P. E. H. Howarth and Mr. R. E. Peasegood, temporary demonstrators in anatomy; Captain J. H. Hale, assistant bacteriologist and demonstrator in bacteriology; Dr. Enid Bankier, demonstrator in zoology to medical and dental students; Mr. W. Davies, research assistant in refractory materials (in addition to his duties as temporary part-time assistant lecturer in geology).

THE British Association of Refrigeration, at its forty-fourth annual meeting, has decided to change its title to the Institute of Refrigeration, the change to take place on March 26, 1944. At the same time, the Association will establish a qualified class of technical membership attainable by examination on the lines of the major engineering institutions.

R. J. BRAIDwood has issued as a reprint from the "1943 Britannica Book of the Year" notes describing recent archæological work in Iraq, Palestine, Kenya, Morocco, England, etc. The notes form an excellent and useful three-page summary of British war-time discoveries and publications in the realm of prehistory. 